\title{
Photoperiodic modulation of circadian rhythms in the silk gland protein profiles of Bombyx mori and its influence on the silk productivity and quality
}

\section{B. Sailaja and S. Sivaprasad*}

Department of Zoology, Smt. N.P.S. Government College for women, Chittoor- 517002 (A.P), INDIA

* Corresponding author. E-mail: sivaprasadzoology@yahoo.co.in

Abstract: Circadian rhythms in the silk gland protein profiles of Bombyx mori were analyzed under $12 \mathrm{~h}$ light and 12 h dark cycle (LD), continuous light (LL) and continuous dark (DD) conditions. The phase response curves of protein rhythms indicate the prevalence of a series of silk cycles, each comprising three phases; transcription, translation and consolidation of silk proteins. In the $24 \mathrm{~h}$ - protein rhythm, the silk cycle repeats every $3 \mathrm{~h}, 42 \mathrm{~m}$ under LD, $2 \mathrm{~h}, 36 \mathrm{~m}$ under LL and $3 \mathrm{~h}$ under DD. The light and dark conditions advanced the rhythm of each silk cycle by $48 \mathrm{~m}$ and $24 \mathrm{~m}$ respectively. As a result the silk gland completes 7 rounds of protein synthesis under LD, 9 rounds under LL and 8 rounds under DD during the $24 \mathrm{~h}$-free running time of the rhythm. The light-induced clock-shift in the protein rhythm caused significant gains in economic parameters of sericulture with positive signals for enhancing silk productivity and quality.

Keywords: Bombyx mori, Circadian rhythms, Photoperiod, Proteins, Silk gland

\section{INTRODUCTION}

The silkgland of Bombyx mori is the principal organ that converts nutrients of mulberry leaves into silk proteins. The productivity and quality of the silk, the exquisite fabric of the sericulture industry, largely depends on the growth of the silk gland and the timing of the silk proteins synthesized in it. In view of its economic importance, the silk gland of Bombyx mori and other silk moths has been extensively probed. (eg. Obara and Suzuki, 1988; Michaille et al., 1989; Gizelak, 1995; Inoue et al., 2000; Yong Houet al., 2007; Durand et al., 1992 and Fukuta et al., 1993). One of the important lines of investigations concentrated on the identification, isolation and cloning of circadian clock genes and their products and unraveling the molecular and genetic mechanism of circadian rhythms. A large number of circadian clock genes such as period (per), timeless (tim), double time (dbt) and the clock proteins such as the PER (PERIOD), TIM (TIMELESS), CRY (CRYPTOCHROME), CYC (CYCLE), DBT (DOUBLE TIME), CLK (CLOCK), were identified in silk moths and specific functions were assigned to them (Sharma, 2003; Sehadova et al, 2004 and Iwai et al., 2006). Concerted efforts were also made to localize the endogenous pace makers or circadian clocks or oscillators in a variety of insects (Glossop and Hardin, 2002; Sehadova et al., 2004 and Reppert, 2006).

The studies on circadian rhythms largely highlighted the transcriptional and translational profiles of clock genes in Bombyx mori. The molecular and genetic mechanism of circadian clock genes needs to be substantiated in terms of biochemical and physiological manifestations. No effort has since been made to elucidate the biochemical basis of circadian clock mechanism and its implications for silk production. Studies on the silkgland circadian behaviour could provide vital clues on the mysteries of silk genes and the timing of their expression that could have strong influence on the quality and productivity of the silk. The present investigation aims at making a preliminary attempt in this direction.

\section{MATERIALS AND METHODS}

The present investigation was carried out on the Pure Mysore $\mathrm{x} \mathrm{CSR}_{2}$ hybrid variety of the silkworm Bombyx mori, reared under standard environmental conditions of $28^{\circ} \mathrm{C}, 85 \% \mathrm{RH}$, as described by Krishnaswami (1986). After hatching the worms were fed with $\mathrm{M}_{5}$ variety of mulberry leaves, 5 times a day at 6AM, 10 AM, 2 PM, $6 \mathrm{PM}$ and $10 \mathrm{PM}$ under $12 \mathrm{~h}$ light and $12 \mathrm{~h}$ dark cycle. After the third moult, the larvae were divided into three batches and reared separately under three different photoperiodic conditions, viz., $12 \mathrm{~h}$ light and $12 \mathrm{~h}$ dark cycle (LD), continuous light (LL) and continuous dark (DD) with five feeds a day as earlier. The investigation was divided into two parts; the assay of circadian rhythms in the silk gland protein profiles and the analysis of economic parameters of sericultural importance.

i) Assay of circadian protein rhythms: Circadian rhythmicity in the protein profiles of the silk gland was analyzed on the fifth day of fifth instar throughout the day. The silk glands, isolated every hour by dissecting the silkworm larvae in ice-cold Silkworm Ringer (Yamaoka 
et al., 1971), starting from $8 \mathrm{AM}$ on day-5 till $8 \mathrm{AM}$ on day-6 (i.e. for 25 hours), were used for the assay of proteins. Hour-to-hour changes in protein profiles of the silk gland were analyzed and the levels of total and soluble proteins of the silk glands were estimated in $1 \%$ homogenates of the tissue in ice cold distilled water, by the method of Lowry et al. (1951). The levels of structural proteins were deduced from the levels of total and soluble proteins by subtracting the later from the former.

The experiment lasted for two consecutive days encompassing 12: 12 hours of light and dark cycle (LD) for the first batch, continuous light (LL) for the second batch and continuous dark (DD) for the third batch. In the LD condition, the study duration was divided into two photo (light) phases and one scoto (dark) phase. The first light phase extended from $8 \mathrm{~h}$ to $18 \mathrm{~h}$ on day- 5 lasting for a duration of 10 hours, and the second light phase extended for two hours on day-6, i. e from $6 \mathrm{~h}$ to 8 $\mathrm{h}$. The duration of dark phase lasted for $12 \mathrm{~h}$, i.e. from 18 $\mathrm{h}$ on day- 5 to $6 \mathrm{~h}$ on day- 6 at a single stretch. The batch of the silkworm larvae reared under LD was treated as the control and those reared under LL and DD as the experimental samples.

ii) Analysis of economic parameters: Some important economic parameters of the sericulture industry were analyzed as per the methods given by Bohidar etal.(2007) and Rahmathulla et al. (2007). The ripened worms were mounted separately and the economic traits such as the larval weight, silk gland weight, gland-body ratio, cocoon weight, cocoon-shell weight, cocoon - shell ratio, renditta, raw silk - larval body ratio, raw silk percentage, filament weight, denier (filament size), floss-shell ratio were analyzed separately in each batch. Additionally, the protein content of the shell and floss of the cocoon was also ascertained as per the method given by Lowryet al. (1951).

\section{RESULTS}

The results of the current study encompasses two aspects; photoperiodic modulation of circadian rhythms in the silk gland protein profiles and its impact on economic parameters of sericulture.

\section{Photoperiodic modulation of circadian changes in protein}

profiles: Hour-to-hour changes in the levels of total, soluble and structural proteins of the silk gland, assayed under LD, LL and DD conditions for a period of $24 \mathrm{~h}$ is designated as the free running period or the tau. The data pertaining to protein profiles are presented graphically in the form of phase response curves (PRCs) in figure 1. The elevated points (both major and minor) in the protein levels were treated as peaks and the low points or depressions (both major and minor) as troughs, which represent two phases of the protein rhythm.

i) Total proteins: Under 12:12 light / dark cycle, the total protein content of the silk gland showed 7 peaks,
( $8 \mathrm{~h}, 13 \mathrm{~h}, 16 \mathrm{~h}, 20 \mathrm{~h}, 23 \mathrm{~h}, 2 \mathrm{~h}$ and the last one next day at $6 \mathrm{~h})$ and 7 troughs $(12 \mathrm{~h}, 15 \mathrm{~h}, 18 \mathrm{~h}, 22 \mathrm{~h}, 00 \mathrm{~h}, 3 \mathrm{~h}$ and the last one next day at $8 \mathrm{~h}$ )) during the $24 \mathrm{~h}$ free running period of the circadian rhythm (Fig. 1 A). Of the 7 peaks and 7 troughs, four each were recorded during the photo phase and three each during the scoto phase of the light-dark cycle. Under LL, the protein rhythm recorded 9 peaks (8h, 10h, 12h, 15h, 17h, 19h, 21h, 3h and the last one next day in between $6-7 \mathrm{~h}$ ) and 9 troughs $(9 \mathrm{~h}, 11 \mathrm{~h}, 13 \mathrm{~h}, 16 \mathrm{~h}$, $18 \mathrm{~h}, 20 \mathrm{~h}, 23 \mathrm{~h}, 4 \mathrm{~h}$ and the last one next day at $8 \mathrm{~h})$. Similarly, 7 peaks $(10 \mathrm{~h}, 13 \mathrm{~h}, 15 \mathrm{~h}, 19 \mathrm{~h}, 00 \mathrm{~h}, 4 \mathrm{~h}$, and $7 \mathrm{~h}$ ) and 7 troughs $(11 \mathrm{~h}, 14 \mathrm{~h}, 16 \mathrm{~h}, 21 \mathrm{~h}, 2 \mathrm{~h}$, and the last two next day at $6 \mathrm{~h}$ and $8 \mathrm{~h}$ ) were recorded under DD. During the remaining free running period of rhythm, all the protein levels maintained constant fluctuations that are not statistically significant to be counted as peaks and troughs. The interval between different peaks and troughs ranged from 2 to 7 hours under three photoperiodic conditions (Tables 1 and 2). However, the computed mean interval between two peaks and two troughs was $\sim 3 \mathrm{~h}$ under LD, $\sim 2.5 \mathrm{~h}$ under LL and $\sim 3 \mathrm{~h}$ under DD.

ii) Soluble proteins: The soluble protein levels of the silkgland showed 7 peaks $(8 \mathrm{~h}, 16 \mathrm{~h}, 19 \mathrm{~h}, 23 \mathrm{~h}, 2 \mathrm{~h}, 5 \mathrm{~h}$ and the last one next day at $8 \mathrm{~h})$ and 7 troughs $(9 \mathrm{~h}, 14 \mathrm{~h}, 18 \mathrm{~h}$, $21 \mathrm{~h}, 00-01 \mathrm{~h}, 4 \mathrm{~h}$ and the last one next day at $6 \mathrm{~h}$ ) under $\mathrm{LD}$, of which three appeared during the photo phase and four during the scoto phase of the rhythm, Likewise, the soluble protein profiles of silk gland showed 9 peaks ( $8 \mathrm{~h}, 11 \mathrm{~h}, 13 \mathrm{~h}, 15 \mathrm{~h}, 18 \mathrm{~h}, 20 \mathrm{~h}, 22 \mathrm{~h}, 2 \mathrm{~h}$ and the last one next day at $8 \mathrm{~h})$ and 9 troughs $(9 \mathrm{~h}, 12 \mathrm{~h}, 14 \mathrm{~h}, 16 \mathrm{~h}, 19 \mathrm{~h}, 21 \mathrm{~h}, 23 \mathrm{~h}$, $3-4 \mathrm{~h}$ and the last one next day at $6 \mathrm{~h}$ ) under LL, but 9 peaks (10h, 13h, 15-16h, 19h, 21h, 00h, 3h, 5h and the last one next day at $7 \mathrm{~h})$ and 10 troughs $(8 \mathrm{~h}, 12 \mathrm{~h}, 14 \mathrm{~h}, 17 \mathrm{~h}, 20 \mathrm{~h}$, $22 \mathrm{~h}, 2 \mathrm{~h}, 4 \mathrm{~h}$ and the last two next day at $6 \mathrm{~h}$ and $8 \mathrm{~h}$ ) under DD (Fig. 1-B). During the remaining period of the rhythm, soluble protein levels maintained minor ups and downs, which are of least significance to be considered as peaks and troughs (Fig. 1-B). Though, the individual intervals between any two peaks or troughs ranged from 2 to $6 \mathrm{~h}$, the computed mean value stood at $\sim 3 \mathrm{~h}$ under $\mathrm{LD}, 2.5 \mathrm{~h}$ under LL and $\sim 2 \mathrm{~h}$ under DD (Tables 1 and 2).

iii) Structural Proteins: Under 12:12 light / dark cycle (LD), the levels of structural proteins showed 8 peaks ( $8 \mathrm{~h}, 13 \mathrm{~h}, 17 \mathrm{~h}, 20 \mathrm{~h}, 23 \mathrm{~h}, 2 \mathrm{~h}, 4 \mathrm{~h}$ and the last one next day at $6 \mathrm{~h})$ ) and 8 troughs $(12 \mathrm{~h}, 15 \mathrm{~h}, 19 \mathrm{~h}, 22 \mathrm{~h}, 00 \mathrm{~h}, 3 \mathrm{~h}, 5 \mathrm{~h}$ and the last one next day at $8 \mathrm{~h}$ ) during the $24 \mathrm{~h}$-free running period of the circadian rhythm (Fig.1. C). Of all, 4 peaks and 3 troughs appeared during the photo phase and the remaining ones appeared during scoto phase. Under continuous light (LL), 8 peaks ( $8 \mathrm{~h}, 12 \mathrm{~h}, 14-15 \mathrm{~h}, 17 \mathrm{~h}, 19 \mathrm{~h}$, $21 \mathrm{~h}, 3 \mathrm{~h}$ and the last one next day in between $6-7 \mathrm{~h}$ ) and 8 troughs (11h, 13h, 16h, 18h, 20h, 23h, 4h and the last one next day at $8 \mathrm{~h}$ ) were recorded in the levels of structural proteins of the silk gland.Under continuous dark (DD) 


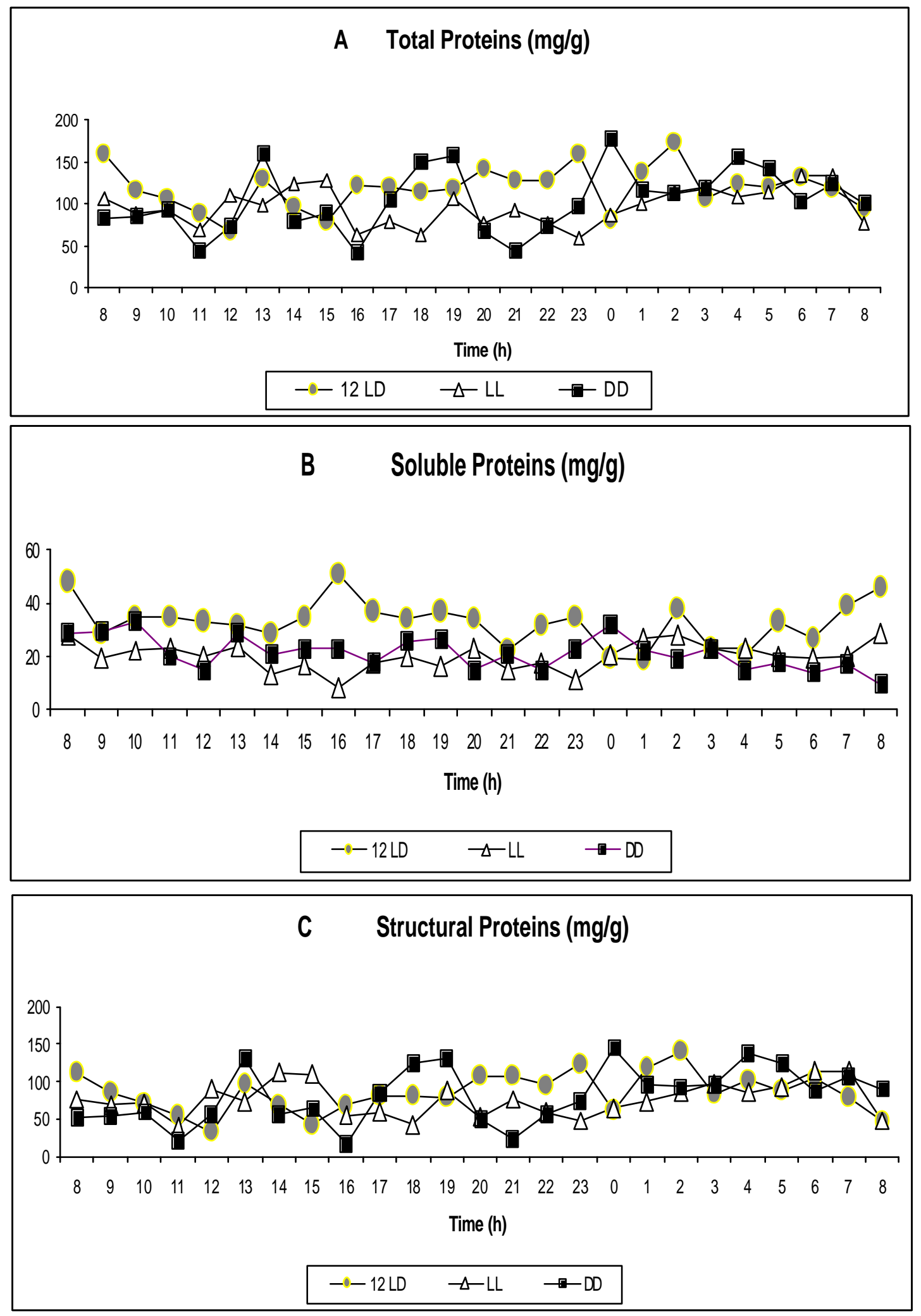

Fig. 1. Phase response curves $(P R C)$ of the circadian protein rhythms in respect of total $(A)$, soluble $(B)$ and structural $(C)$ proteins in the silk gland of Bombyx mori, under 12h light: 12h dark cycle (LD); continuous light (LL) and continuous dark (DD) conditions. Each phase represents the hourly assay of protein levels, starting from $8 \mathrm{~h}$ on day-5 to $8 \mathrm{~h}$ on day-6 during fifth instar development. Each value, expressed as mg protein / $g$ wet weight of tissue represents the mean \pm S.D offour separate observations; ( $P$ values: $<0.001)$. 


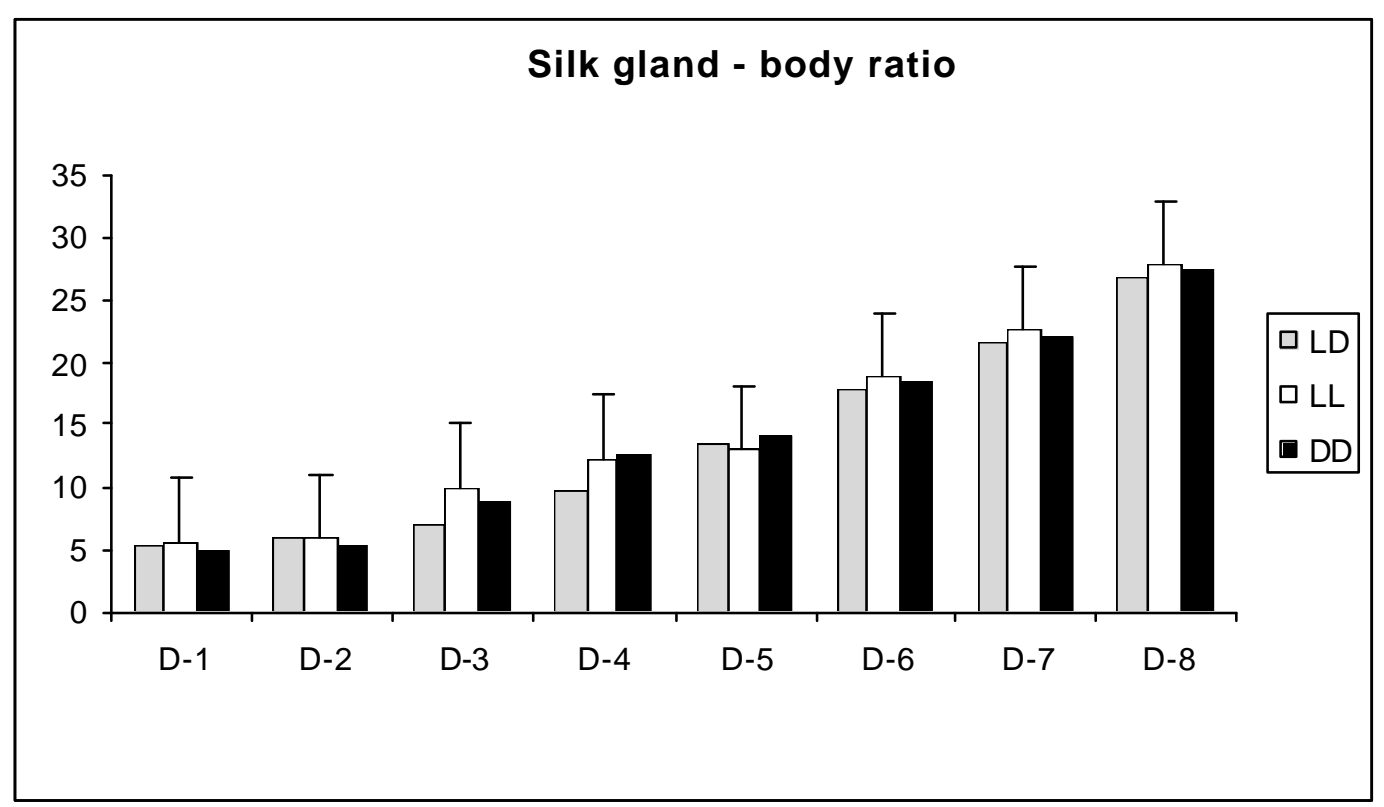

Fig.2. Growth of the silk gland - body ratio during fifth instar development of Bombyx mori, under $12 \mathrm{~h}$ light and $12 \mathrm{~h}$ dark cycle $(L D)$, continuous light $(L L)$ and continuous dark $(D D)$. Each value is a mean, \pm standard deviation offour individual observations. (P value < 0.001). D -1 to D- 8: Day-1 to day-8 of fifth instar.

the structural protein content of the silk gland recorded 7 peaks $(10 \mathrm{~h}, 13 \mathrm{~h}, 15 \mathrm{~h}, 19 \mathrm{~h}, 00 \mathrm{~h}, 4 \mathrm{~h}$ and the last one next day at $7 \mathrm{~h})$ and 7 troughs $(11 \mathrm{~h}, 14 \mathrm{~h}, 16 \mathrm{~h}, 21 \mathrm{~h}, 1-2-3 \mathrm{~h}$ and the last two next day at $6 \mathrm{~h}$ and $8 \mathrm{~h}$ ) during the $24 \mathrm{~h}$ free running period of the rhythm (Fig.1. C). During the remaining period of the free running time, the structural protein levels maintained minor ups and downs, which are of least significance. Though, the individual intervals between any two peaks or troughs ranged from 2 to $6 \mathrm{~h}$, the mean interval between any two peaks or troughs stood at 2.8h under LD, 2.6h under LL and $\sim 3$ under DD (Tables 1 and 2).

Photoperiodic modulation of economic parameters: The data pertaining to the economic parameters are presented in Table 3 and Fig. 2.

The growth of larval body and the silk gland under three photoperiodic conditions, measured in terms of daily changes in their weights during the fifth instar development is presented in Fig. 2. Under $12 \mathrm{~h}$ light / 12 h dark cycle (LD), the bodyweight recorded significant increases of $342 \%$ from day- 1 through day- 8 of the fifth instar. At the same time, the silk gland exibits a growth rate of about $2014 \%$. Under continuous light condition, the larval body weight showed an overall increase of about $359 \%$ and the silk gland had an increase of $2139 \%$ during fifth instar. Under continuous dark condition, the larval body weight increased to about $364 \%$, while the silkgland grew about $2458 \%$. The silk gland body ratio

Table 1. Interval between peaks (elevated points) of protein levels in the silk gland of Bombyx moriduring the free running period of the protein rhythm under 12h light / 12h dark cycle (LD); continuous light (LL) and continuous dark (DD).

\begin{tabular}{|c|c|c|c|c|c|c|c|c|c|c|c|c|}
\hline \multirow[t]{2}{*}{ Protein type } & \multirow{2}{*}{$\begin{array}{l}\text { Photo- } \\
\text { period }\end{array}$} & \multirow{2}{*}{$\begin{array}{l}\text { No. of } \\
\text { peaks }\end{array}$} & \multicolumn{9}{|c|}{ Interval between peaks in hours } & \multirow{2}{*}{$\begin{array}{c}\text { Mean } \\
\text { interval } \\
\text { in hours }\end{array}$} \\
\hline & & & $1-2$ & $2-3$ & $3-4$ & $4-5$ & $5-6$ & $6-7$ & $7-8$ & $8-9$ & $9-10$ & \\
\hline \multirow{3}{*}{$\begin{array}{c}\text { Total } \\
\text { Proteins }\end{array}$} & LD & 7 & 5 & 3 & 4 & 3 & 3 & 4 & - & - & - & 3.1 \\
\hline & LL & 9 & 2 & 2 & 3 & 2 & 2 & 2 & 7 & 3 & - & 2.3 \\
\hline & DD & 7 & 3 & 2 & 4 & 5 & 4 & 3 & - & - & - & 3.1 \\
\hline \multirow{3}{*}{$\begin{array}{l}\text { Soluble } \\
\text { proteins }\end{array}$} & $\mathrm{LD}$ & 7 & 7 & 3 & 4 & 3 & 3 & 3 & - & - & - & 3.3 \\
\hline & LL & 9 & 3 & 2 & 2 & 3 & 2 & 2 & 4 & 6 & - & 2.7 \\
\hline & DD & 9 & 3 & 2 & 3 & 2 & 3 & 3 & 2 & 2 & - & 2.2 \\
\hline \multirow{3}{*}{$\begin{array}{c}\text { Structural } \\
\text { Proteins }\end{array}$} & $\mathrm{LD}$ & 8 & 5 & 4 & 3 & 3 & 3 & 2 & 2 & - & - & 2.8 \\
\hline & LL & 8 & 4 & 2 & 2 & 2 & 2 & 6 & 3 & - & - & 2.6 \\
\hline & DD & 7 & 3 & 2 & 4 & 5 & 4 & 3 & - & - & - & 3.0 \\
\hline
\end{tabular}

Source: Fig. 1 
Table 2. Interval between troughs (low points) of protein levels in the silk gland of Bombyx mori during the free running period of the protein rhythm under 12h light / 12h dark cycle (LD); continuous light (LL) and continuous dark (DD).

\begin{tabular}{|c|c|c|c|c|c|c|c|c|c|c|c|c|}
\hline \multirow[t]{2}{*}{ Protein type } & \multirow{2}{*}{$\begin{array}{l}\text { Photo- } \\
\text { period }\end{array}$} & \multirow{2}{*}{$\begin{array}{l}\text { No. of } \\
\text { troughs }\end{array}$} & \multicolumn{9}{|c|}{ Interval between troughs in hours } & \multirow{2}{*}{$\begin{array}{l}\text { Mean } \\
\text { interval } \\
\text { in hours }\end{array}$} \\
\hline & & & $1-2$ & $2-3$ & $3-4$ & $4-5$ & $5-6$ & $6-7$ & $7-8$ & 8-9 & 9-10 & \\
\hline \multirow{3}{*}{$\begin{array}{c}\text { Total } \\
\text { Proteins }\end{array}$} & $\mathrm{LD}$ & 7 & 3 & 3 & 4 & 2 & 3 & 5 & - & - & - & 2.9 \\
\hline & LL & 9 & 2 & 2 & 3 & 2 & 2 & 3 & 5 & 4 & - & 2.6 \\
\hline & DD & 7 & 3 & 2 & 5 & 5 & 4 & 2 & - & - & - & 3.0 \\
\hline \multirow{3}{*}{$\begin{array}{l}\text { Soluble } \\
\text { proteins }\end{array}$} & $\mathrm{LD}$ & 7 & 5 & 4 & 3 & 3 & 4 & 2 & - & - & - & 3.0 \\
\hline & LL & 9 & 3 & 2 & 2 & 3 & 2 & 2 & 4 & 3 & - & 2.3 \\
\hline & DD & 10 & 4 & 2 & 3 & 3 & 2 & 4 & 2 & 2 & - & 2.2 \\
\hline \multirow{3}{*}{$\begin{array}{l}\text { Structural } \\
\text { Proteins }\end{array}$} & $\mathrm{LD}$ & 8 & 3 & 4 & 3 & 2 & 3 & 2 & 5 & - & - & 2.8 \\
\hline & LL & 8 & 2 & 3 & 2 & 2 & 3 & 5 & 4 & - & - & 2.6 \\
\hline & DD & 7 & 3 & 2 & 5 & 4 & 3 & 2 & - & - & - & 2.7 \\
\hline
\end{tabular}

Source: Fig. 1.

showed an increase of $379 \%$ under LD, of $390 \%$ under LL and under DD conditions it rose to $450 \%$ (Fig. 2 ).

The remaining 12 other economic parameters, viz., weight of single cocoon, shell with floss, shell without floss, floss of single shell, floss of shell ratio, shell proteins of single cocoon, floss proteins of single cocoon, silk filament weight per shell, raw silk-larval body ratio, raw silk percentage, renditta and denier (Table 3 ) have shown positive growth trends in the silkworms reared under continuous light (LL) and continuous dark (DD) conditions, compared to those reared under $12 \mathrm{~h}$ light 12 h dark cycle (LD).

\section{DISCUSSION}

The silk gland is a repository of over 93 proteins that includes both soluble and structural components (Jin et al., 2004; Zhang et al. 2006 and Yong Hou et al., 2007). Prominent soluble proteins of the silk gland in Bombyx mori include chaperones, metabolic enzymes like triose phosphate isomerase, enolase and inorganic pyrophosphate, heat shock proteins, immuno proteins, serpins, transport proteins and those involved in replication, transcription and translation of silk proteins, (Yang Hou, et al., 2007; Kyunget al., 2006). The structural proteins comprise several cocoon proteins (Nirmala et $a l ., 2001$ ) and silk proteins (Inoue et al., 2000; Takasu et al., 2005), and cytoskeleton proteins like actins, tubulins, transmembrane proteins and many more (Yong Hou et al., 2007).

The current study demonstrates the prevalence of circadian protein rhythm in the silk gland of Bombyx mori that manifests in the profiles of total, soluble and structural proteins (Fig.1). Our findings are in consistence with reports that highlighted the existence of tissue specific circadian rhythms in Bombyx mori (Sehadova etal., 2004; Iwai et al., 2006; Kyung et al., 2006; Yong Hou et al., 2007). Circadian rhythms enable organisms to live in harmony with the rhythms of the nature by re-adjusting their physiological events to occur at an appropriate time of the day (Saunders, 2002). Light being the most dominant zeitgeber (time giver), modulates the circadian clock mechanism by entrainment or clock-shifting phenomenon during the larval development ( Peschel et al.,2009) which involves the continuation of the circadian rhythm, but setting it ahead or behind the normal free running time (Wallace et al., 1991).

The phase response curves (PRCs) of the protein rhythm, with its characteristic ups (peaks) and downs (troughs) show the profound effect of altered photoperiodic conditions on the circadian protein rhythm in the silk gland of Bombyx mori. We presume that the peaks represent intense phases of protein biosynthesis and the troughs the declining trend in protein synthesis during the free running period of the rhythm. The troughs may also indicate the mobility of some clock related proteins from the cytosol to the nucleus and the timebound homeostatic mechanism that facilitate the degradation of selected proteins by intracellular proteolysis (by proteases) that characterize the silkworm metamorphosis (Chen and You, 2004 and Ciechanover, 2005). The analysis of PRCs, in terms of the mean number of peaks and troughs and mean interval between them gives meaningful results. Notwithstanding the individual fluctuations in the number of peaks and troughs, their combined mean value is of $\sim 7$ under LD, $\sim 9$ under LL and $\sim 8$ under DD, while their combined mean interval is $\sim 3.4$ $\mathrm{h}$ under LD, $2.6 \mathrm{~h}$ under LL and exactly $3 \mathrm{~h}$ under DD.

On the basis of rhythmic changes in the protein profiles observed in the current study, we propose a $24 \mathrm{~h}$-circadian silk rhythm that could possibly operate in the silk gland of Bombyx mori during the fifth instar development. This rhythm includes a series of silk cycles that are repeated $\sim 7$ times under LD, $\sim 9$ times under LL and $\sim 8$ times under 
Table 3. Photoperiodic modulation of economic parameters of the silkworm, Bombyx mori, under $12 \mathrm{~h}$ light and $12 \mathrm{~h}$ dark cycle (LD), continuous light (LL) and continuous dark (DD). The weight of the cocoon, shell and floss represents the mean of 25 individual cocoons. Each value is a mean \pm standard deviation of four individual observations. The values in parentheses represent the percent changes computed by taking the LD as the control.

\begin{tabular}{|c|c|c|c|c|c|}
\hline & Parameter & & $\begin{array}{l}12 \text { h light / } 12 \text { h } \\
\text { dark cycle } \\
\text { (L D) }\end{array}$ & $\begin{array}{c}\text { Continuous } \\
\text { Light } \\
\text { (L L) }\end{array}$ & $\begin{array}{c}\text { Continuous } \\
\text { Dark } \\
\text { (D D) }\end{array}$ \\
\hline \multirow[t]{3}{*}{1.} & Weight of single green cocoon $(\mathrm{g})$ & Mean & 0.976 & 1.000 & 0.984 \\
\hline & & P.C & - & $(+2.5)$ & $(+0.8)$ \\
\hline & & S.D & \pm 0.001 & $\pm 0.001 *$ & $\pm 0.001 *$ \\
\hline \multirow[t]{3}{*}{2.} & Weight of the single shell with floss (g) & Mean & 0.189 & 0.189 & 0.188 \\
\hline & & P.C & - & $(+0.0)$ & $(-0.5)$ \\
\hline & & S.D & \pm 0.001 & $\pm 0.001 * *$ & $\pm 0.001 * *$ \\
\hline \multirow[t]{3}{*}{3.} & Weight of single shell without floss (g) & Mean & 0.166 & 0.172 & 0.170 \\
\hline & & P.C & - & $(+3.6)$ & $(+2.4)$ \\
\hline & & S.D & \pm 0.001 & $\pm 0.001 *$ & $\pm 0.001 *$ \\
\hline \multirow[t]{3}{*}{4.} & Weight of the floss of single shell $(\mathrm{g})$ & Mean & 0.023 & 0.017 & 0.018 \\
\hline & & P.C & - & $(-26.1)$ & $(-21.7)$ \\
\hline & & S.D & 0.001 & $\pm 0.001 *$ & $\pm 0.001 *$ \\
\hline \multirow[t]{3}{*}{5.} & Floss - shell ratio & Mean & 13.9 & 9.9 & 10.6 \\
\hline & & P.C & - & $(-28.8)$ & $(-23.7)$ \\
\hline & & S.D & 0.01 & $\pm 0.01 *$ & $0.01 *$ \\
\hline \multirow[t]{3}{*}{6.} & Total protein content of single shell & Mean & 43.4 & 46.2 & 39.6 \\
\hline & without floss (mg) & P.C & - & $(+6.5)$ & $(-8.8)$ \\
\hline & & S.D & \pm 0.10 & $\pm 0.10^{*}$ & $\pm 0.01 *$ \\
\hline \multirow[t]{3}{*}{7.} & Total protein content in the floss of a & Mean & 6.1 & 4.1 & 4.9 \\
\hline & single shell (mg) & P.C & - & $(-32.8)$ & $(-19.7)$ \\
\hline & & S.D & \pm 0.01 & $\pm 0.01^{*}$ & $\pm 0.01^{*}$ \\
\hline \multirow[t]{3}{*}{8.} & Silk filament weight per shell (g) & Mean & 0.126 & 0.143 & 0.132 \\
\hline & & P.C & - & $(+13.5)$ & $(+4.8)$ \\
\hline & & S.D & \pm 0.001 & $\pm 0.001 *$ & $\pm 0.001 *$ \\
\hline \multirow[t]{3}{*}{9.} & Raw silk - larval body ratio & Mean & 5.70 & 6.12 & 5.84 \\
\hline & & P.C & - & $(+7.4)$ & $(+2.5)$ \\
\hline & & S.D & \pm 0.01 & $\pm 0.01 *$ & $\pm 0.01^{*}$ \\
\hline \multirow[t]{3}{*}{10.} & Raw silk percentage & Mean & 12. 91 & 14. 30 & 13. 41 \\
\hline & & P.C & - & $(+10.8)$ & $(+3.9)$ \\
\hline & & S.D & \pm 0.01 & $\pm 0.01 *$ & $\pm 0.01 *$ \\
\hline \multirow[t]{3}{*}{11.} & Renditta & Mean & 7.93 & 7.01 & 7.56 \\
\hline & & P.C & - & $(-11.6)$ & $(-4.7)$ \\
\hline & & S.D & \pm 0.01 & $\pm 0.01 *$ & $\pm 0.01 *$ \\
\hline \multirow[t]{3}{*}{12.} & Denier & Mean & 17.1 & 14.4 & 13.5 \\
\hline & & P.C & - & $(-15.8)$ & $(-21.1)$ \\
\hline & & S.D & \pm 0.01 & $\pm 0.01 *$ & $\pm 0.01^{*}$ \\
\hline
\end{tabular}

* Statistically significant. ** Statistically not significant.

DD. Each round of the silk cycle includes two vital phases of silk gene expression, i.e., transcription, translation apart from the phase of consolidation. The timing of troughs probably indicate the timing of transcriptional phases, while those of peaks reflect the timing of translation phases. The silk proteins synthesized during the translation phase may assemble and assume secondary and tertiary structures and achieve their functional status during the consolidation phase, which probably occurs during the scotopic phase of the rhythm. Obviously, the ups (peaks) and downs (troughs) in protein levels of the silk gland provide vital clues regarding the expression of silk genes. Presumably, the ups and downs in the levels of soluble and structural proteins indicate the synthesis and consolidation of silk proteins during peak phases that are subjected to modulation by the dark and light cues. The synthetic and consolidation phases are apparently stimulated by the dark cues as evidenced by the appearance of higher peaks in the levels of soluble and structural proteins under LD and DD, compared to those under LL. On the other hand the light seems to have stimulatory effect on the number of protein synthetic cycles as reflected in the increase in the number of peaks and troughs during the free running time of the rhythm (Fig. 1. A, B, C). Thus, the intensity (height of peaks) and frequency (number of peaks) of silk gene expression in Bombyx mori are independently modulated by the dark and light cues respectively. We do not have supportive 
data to establish this fact conclusively. Nonetheless, the available data on circadian clock genes and their timing of expression indirectly lends some support (Grima et al., 2004; Hardin 2004; Shafer et al., 2004; Stoleru et al., 2004). Further, it is evident that the photoperiod is known to cause behavioural adjustments by altering clock gene expressions and the clock time could be advanced by the degradation of TIM during the later half of the night. Further, our assumption is based on the premise that the mRNA synthesis of clock genes was found to be higher on short days than under longer days and that it peaks during the scoto phase (Goto and Denlinger, 2002; Syrova et al., 2003).

The genetical and molecular mechanism of the circadian clock is not corroborated by biochemical studies; as direct evidence for protein rhythms remains unavailable. However, our findings are in agreement with the earlier observations that more proteins are synthesized under altered conditions of photoperiod (Kenny and Saunders, 1991; Koga et al., 2005;Peschel et al., 2009). The control mechanism of circadian behaviour of tissue protein is not known; but it is likely that the juvenile hormone secreted by the corpora allata (Dolezel et al., 2008) does so by modulating the peripheral oscillators of the silk gland. Further, the silk gland maintained the circadian rhythm more or less at a constant rate even under continuous dark condition (DD), probably by taking cues from the diet, in the absence of light. This fact is substantiated by earlier reports (Damiola et al., 2000; Kita et al., 2002; Stokkan et al., 2001) which state that the food can act as prime zeitgeber and that the restricted feeding quickly resets clocks in peripheral organ. Since, the silkworms, reared under continuous dark were also fed 5 times a day, they carried through the rhythm more or less on the same lines as done by the worms grown under LD. It is likely that silkworm might have a dual mode operating system with at least two-oscillators in the silk gland, in which one responds to the light and the other responds to the dark, as observed by Forster (2000) with respect to locomotory rhythm in Drosophila flies. Despite the prevalence of minor variations in the levels of proteins under different photoperiods, our study revealed a clock-shift in all the three types of proteins in the silk gland of Bombyx mori under constant light (LL) and constant dark (DD) conditions. Accordingly, in the silkworms that are deprived of natural light cues, the circadian silk rhythm shifts from the standard $24 \mathrm{~h}$ pattern. In the present case the shift resulted in the advancement of each silk cycle by $48 \mathrm{~m}$ under LL and by $24 \mathrm{~m}$ under DD conditions, thus disturbing the free running time of the circadian silk rhythm both in photo and scoto phases. The $24 \mathrm{~h}$-circadian protein rhythm of LD condition, with 7 rounds of protein synthesis, has been clock-shifted to about $18.2 \mathrm{~h}$ under LL and $21 \mathrm{~h}$ under DD conditions. With the result, the silk gland is able to accomplish 2 additional rounds of protein synthesis under LL and one round under DD during the $24 \mathrm{~h}$-free running time of the silk rhythm.

Influence of protein rhythms on economic parameters: The productivity and profitability of the sericulture industry largely depend on the quantity and quality of silk proteins. Both these parameters are influenced by the rhythm it maintains with regard to protein synthesis. Any progressive change in the style of functioning of silk gland will have long-lasting impact on the economic parameters of sericulture. The silk gland of the silkworms reared under LL and DD conditions showed promising growth trends compared to those reared under LD.

The positive impact of LL and DD on economic parameters, observed in the present study, is attributable to the increase in the frequency (number of peaks) and intensity (height of peaks) of protein synthetic cycles during the free running time of the circadian protein rhythm. Two additional rounds of protein synthesis in the silk gland under LL (total 9 rounds) and one additional round under DD (total 8 rounds), and a decrease in the interval between protein synthetic cycles (from 3.4h under LD to $2.6 \mathrm{~h}$ under LL and $3 \mathrm{~h}$ under DD) have advanced the silk cycle by $48 \mathrm{~m}$ under LL and $24 \mathrm{~m}$ under DD, resulting in significant rise in all the economic parameters analyzed. For instance, in the silkworms grown under continuous light during the fourth and fifth instars, the silkgland-body ratio significantly increased from 26.8 under LD to 27.9, thus indicating the fact that the silk gland grows at a faster rate under LL compared to LD. Likewise, one additional round of protein synthesis and $24 \mathrm{~m}$ advancement of the free running time of the protein rhythm in the silk gland resulted in raising the glandbody ratio from 26.8 to 27.5 under DD (Fig.2). The other 12 economic parameters were also altered under LL and LD conditions (Table 3 ).

Thus, the circadian protein rhythm modulates the productivity and quality of silk produced by the silk gland. The photoperiod -modulated rhythm under LL has resulted in improving the productivity and quality of silk in two ways; i.e., increasing the silk output and at the same time decreasing the wastage. This is achieved by increasing the synthesis of fibroin, the core silk protein (Inoue et al., 2000; Yong Hou et al., 2007) and by decreasing the synthesis of sericin proteins which constitute the bulk of floss that is chiefly distributed in the outer most layer of the cocoon and is removed as wastage during silk reeling (Takasu et al., 2005). The increasing effect of photoperiod on the fibroin synthesis vis-à-vis its modulatory role on circadian rhythms, is evidenced by improvements in several economic parameters such as the shell weight, silk-body ratio, gland-body ratio, protein content of the shell, raw silk 
percentage and weight of silk thread obtained from a single cocoon. Similarly, the decrease in wastage is substantiated by similar changes in floss-shell ratio, floss protein content and floss weight. Further, the productivity is enhanced significantly by reducing the renditta, from $\sim 8$ under LD, to $\sim 7$ under LL and $~ 7.6$ under DD. The decline in the denier, which is the measure of thickness of the silk thread, from 17.1 in LD to $14.4(-16 \%)$ in LL and $13.5(-21 \%)$ in DD indicates that the silk produced under LL becomes thinner and its texture becomes smoother than those produced under normal day-night cycle. This becomes still thinner in case of the silk thread produced under DD.

The analysis of PRCs (Fig.1), in terms of height (higher protein levels) and number of peaks (silk cycles) provides further insights into the modulatory role of photoperiod on the silk production and productivity. The higher peaks in the protein levels observed under LD and DD, coupled with the trends in floss-related economic parameters, indicate that the dark-light condition (both in LD and DD) stimulates the synthesis of both fibroin and sericin with more emphasis on the later, resulting in the production of more sericin that constitutes the floss of the cocoon. Similarly, more number of silk cycles (i.e. 2 more than LD and 1 more than DD), but with lower protein levels, observed under LL condition, coupled with positive trends in fibroin-related economic parameters reflect that light condition stimulates the synthesis of more fibroin, the core silk protein. If, the observed trends in the economic parameters are an indication, it is presumed that the light condition enhances silk productivity by stimulating fibroin gene expression, while the light-dark condition contributes to higher wastage in silk output by enhancing sericin gene expression, Though, several reports are available on economic parameters of sericulture (Bohidar, et al., 2007; Rahmathulla et al., 2007), our investigations have no parallel supportive documents. Moreover, the study is not exhaustive; nevertheless it provides insights into the utility of photoperiod for profitable sericulture. Extensive field trials involving post-treatment studies with continuous light may go a long way in validating the positive impact of light on the economic parameters of silkworm. The possibility of coupling economic parameters with circadian biochemical rhythm and silk gene expression is thus open for future investigations.

\section{REFERENCES}

Bohidar, K., Sahoo, B.S. and Singh, D.K. (2007). Effect of different varieties of mulberry leaves on economic parameters of the silkworm Bombyx mori L. under orissa climate. Bull. Ind. Acad. Seri., 11(2): 60-64.

Chen, W. and You, Q.(2004). Studies on properties of sericin protein of Bombyx mori Part III : Denaturation and deterioration of sericin at high temperature and high humidities. Bull. Ind Acad. Seri., 8 (1): 23-28.

Ciechanover, A. (2005). Proteolysis: from the lysosome to ubiquitin and the proteasome. Nat. Rev. Mol. Cell Biol., 6: 79-87.

Damiola, F., Le Minh, N., Preitner, N., Kornmann, B., FleuryOlela, F. and Schibler, U. (2000). Restricted feeding uncouples circadian oscillators in peripheral tissues from the central pacemaker in the suprachiasmatic nucleus. Genes Dev., 14 (23): 2950-2961.

Dolezel, D., Zdechovanova, L., Sauman, I. and Hodkova, M. (2008). Endocrine- dependent expression of circadian clock genes in insects. Cell Mol Life Sci., 65(6): 964 -969.

Durand, B., Drevet, J. and Couble, P. (1992). P25 gene regulation in Bombyx mori silk gland: two promoter binding factors have distinct tissue and developmental specificities. Mol. Cell Biol., 12: 5768 - 5777.

Forster, C.H. (2000). Differential control of morning and evening components in the activity rhythm of Drosophila melanogaster -sex- specific differences suggest a different quality of activity. J. Biol. Rhythms, 15(2): 135-154.

Fukuta, M., Matsuno, K., Hui, C., Nagata, T., Takiya, S., Xu, P.-X., Ueno, K. and Suzuki, Y. (1993). Molecular cloning of a POU domain-containing factor involved in the regulation of the Bombyx sericin-1 gene. J. Boil. Chem., 268:1947119475.

Glossop, N.P. and Hardin, P.E. (2002). Central and peripheral circadian oscillator mechanisms in flies and mammals. Journal of Cell Science, 115: 3369-3377.

Goto, S.G. and Denlinger, P.E. (2002). Short-day and long-day expression patterns of genes involved in the flesh fly clock mechanism: period, timeless, cycle and cryptochrome. Journal of Insect Physiology, 48: 803-816.

Gizelak, K. (1995). Control of expression of silk protein genes. Comp. Biochem. Physiol. B: Biochem. Mol. Boil., 110: 671-681.

Grima, B., Chelot, B.E., Xia, R. and Rouyer, F. (2004). Morning and evening peaks of activity rely on different clock neurons of the Drosophila brain. Nature, 431:862-868.

Hardin, P.E. (2004). Transcription regulation within the circadian clock: the E - box and beyond. J.Biol.Rhythms,19: $348-360$.

Inoue, A., Tanaka, K. and Arisakaffi, F. (2000). Silk fibroin of Bombyx mori is secreted, assembling a high molecular mass elementary unit consisting of $\mathrm{H}-$ chain,L-chain, and P25, with a 6:6:1 molar ratio. J. Biol. Chem., 275: 4051740528.

Iwai, S., Fukui, Y., Fujiwara, Y. and Takeda, M. (2006). Structure and expressions of two circadian clock genes, period and timeless in the commercial silkmoth Bombyx mori. J. Insect Physiol., 52(6): 625-637.

Jin, Y.X., Chen, Y.Y., Xu, M.K. and Jiang, Y.H. (2004). Studies on middle silk gland proteins of cocoon colour sex-limited silkworm (Bombyx mori) using two-dimensional polyacrylamide gel electrophoresis. J. Biosci., 29: 45-49.

Kenny, N.A. and Saunders, D.S. (1991). Adult locomotor rhythmicity as "hands" of the maternal photoperiodic clock regulating larval diapause in the blowfly,Calliphora vicina. J. Biol. Rhythms, 6: 217 -233.

Kita, Y., Shiozawa, M., Jin, W., Majewski, R. R., Besharse, J.C., Greene, A.S. and Jacob, H.J. (2002). Implications of 
circadian gene expression in kidney, liver and the effects of fasting on pharmacogenomic studies. Pharmacogenetics, 12(1): 55-65.

Koga, M., Ushirogawa, H. and Tomioka, K. (2005). Photoperiodic modulation of circadian rhythms in the cricket, Gryllus bimaculatus. J. Insect Physiol., 51:219- 230.

Krishnaswami, S. (1986). New technology of silkworm rearing. Central Sericultural Research and Training Institute, Mysore, India.

Kyung, H.S., Su, J.J., Young, R.S., Seok, W.K. and Sung, S.H. (2006). Identification of up-regulated proteins in the hemolymph of immunized Bombyx mori larvae. Comp. Biochem. Physiol., D 1: 260-266.

Lowry, O.H., Rosebrough, N.J., Farr, A.L. and Randall, R.J. (1951). Protein measurement with folin-phenol reagent. $J$. Biol. Chem., 193: 265 - 275.

Michaille, J.J., Garel, A. and Prudhomme, J.C. (1989). The expression of five middle silk gland specific genes is territorially regulated during the larval development of Bombyx mori. Insect Biochem., 19: 19-27.

Nirmala, X., Mita, K., Vanisree, V., Zurovec, M. and Sehnal, F. (2001). Identification of four small molecular mass proteins in the silk of Bombyx mori.Insect Mol., 10: 437445.

Obara, T. and Suzuki, Y. (1988). Temporal and spatial control of silk gene transcription analyzed by nuclear run-on assay. Devl. Biol., 127: 384-391.

Peschel, N., Chen, K.F., Szabo, G. and Stanewsky, R. (2009). Light-dependent interactions between the Drosophila circadian clock factors cryptochrome, jetlag, and timeless. Curr Biol., 19(3): 241- 247.

Rahmathulla, V.K., Priyabrata Das, Ramesh, M. and Rajan, R.K.(2007). Growth rate pattern and economic traits of silkworm, Bombyx mori L under the influence of folic acid administration. J. Appl. Sci. Environ. Manage., 11(4): 81 84.

Reppert, S.M. (2006). A colorful model of the circadian clock. Cell, 124: 233-236.

Saunders, D.S. (2002). Insect Clocks. $3^{\text {rd }}$ ed. Elsevier, Amsterdam.
Sehadova, H., Markova, E.P., Sehnal, F. and Takeda, M.(2004). Distribution of circadian clock related proteins in the cephalic nervous system of the silkworm, Bombyx mori. Journal of Biological Rhythms, 19:466-482.

Shafer, T.O., Levine, J.D., Truman, J.W. and Hall, J.C. (2004). Flies by night: Effects of changing day length on Drosophila's circadian clock. Curr Biol., 14 (5): 424 - 432. Sharma, V.K. (2003). Adaptive significance of circadian clocks. Chronobiol.Int., 20:901 - 919.

Stokkan, K.A., Yamazaki, S., Tei, H., Sakaki, Y. and Menaker, M. (2001).Entrainment of the circadian clock in the liver by feeding. Science, 291(5503): 490-493.

Stoleru, D., Peng, Y., Agosto, J. and Rosbash, M. (2004). Coupled oscillators control morning and evening locomotor behaviour of Drosophila. Nature, 431:862-868.

Syrova, Z., Dolezel, D., Saumann, I. and Hodkova, M. (2003). Photoperiodic regulation of diapause in linden bugs: Are period and clock genes involved? Cell. Mol. Life Sci., 60: 2510-2515.

Takasu, Y., Yamada, H., Saito, H. and Tsubouchi, K. (2005). Characterization of Bombyx mori Sericins by the Partial Amino Acid Sequences. J. Insect Biotechnology and Sericology, 74: 103-109.

Wallace,R.A., Sanders, G.P. and Ferl, R.J. (1991). Adaptiveness of Behaviour. In Wallace,R.A. (Ed.), Biology : the Science of Life (pp 1105 - 1133), HarperCollins Publishers Inc, New York, USA.

Yamaoka, K., Hoshino, M. and Hirai, T.(1971). Role of sensory hairs on the anal papillae in oviposition behaviour of Bombyx mori. J. Insect Physiol.,47: 2327 - 2336.

Yong Hou, Qingyou Xia, Ping Zhao, Yong Zou, Hongli Liu, Jian Guan, Jing Gong and Zhonghuai Xiang. (2007). Studies on middle and posterior silk glands of silkworm (Bombyx mori) using two-dimensional electrophoresis and mass spectrometry. Insect Biochem. Mol Biol., 37: 486-496.

Zhang, P.B., Aso, Y.K., Yamamoto, Banno, Y., Wang, Y.Q., Tsuchida, K.Y.,Kawaguchi and Fujii, H. (2006). Proteome analysis of silk gland proteins from the silkworm, Bombyx mori. Proteomics, 6: 2586 - 2599. 